\title{
SYNTACTICAL ANALYSIS OF THE ENGLISH AND RUSSIAN SUPERSTITIONS
}

\author{
Ekaterina Fliginskikh ${ }^{1 *}$, Galina Semenova ${ }^{2}$ \\ ${ }^{1}$ Prof., Mari State University, RUSSIA, katenasmile@mail.ru \\ ${ }^{2}$ Full Prof. Dr. habil., I.N. Ulyanova Chuvash State University, RUSSIA, gncemenova@yandex.ru \\ ${ }^{*}$ Corresponding author
}

\begin{abstract}
Superstitions present a special group of paroemiae which is wide-spread in any language and any culture. They accumulate the experience of generations and present it in the original form. The article analyses superstitions of the English and Russian languages from the syntactical point of view. The authors consider folk superstitions connected with the rites of passage, such as pregnancy, birth, wedding, and death.

The authors present two types of analysis: structural analysis and functional analysis. Structural analysis describes different types of sentences according to their structure and connections of words within a sentence. The authors distinguish clauses of conditions and consequence, etc. Functional analysis describes different types of sentences according to their functions. Authors distinguish prognostic superstitions, intention superstitions, taboo superstitions, and apotropaic superstitions. All of them have different structure depending on the function they perform. It is interesting to note that functional analysis is common for all three languages under study. Sentences have similar structure and may be presented as loan translation. At the same time, structural analysis underlines the difference between the languages in general and between sentence building of different languages in particular.

In the research to select the material for the purpose of study the authors used a continuous sampling method, registration and processing of the data received, observation, analysis of each group of superstitions, a comparative analysis of the superstitions, statistical method. All these methods allow making a comprehensive and detailed analysis of the units under study. The presented examples prove the theoretical statements.
\end{abstract}

Keywords: superstitions, phrases, sentences, English language, Russian language

\section{INTRODUCTION}

The present study is aimed at making a structural and functional syntax analyses of the texts of connected with such rites of passage as pregnancy, birth, wedding, and death in the English and Russian languages. Such analyses will reveal universal and unique features concerning sentence building in the languages under study and will present the constructions typical of the superstitions of the English and Russian languages. 
The present paper is one of the works of the authors devoted to the superstitions. Superstitions as verbalized units in the form of sentences which appeared a lot of years ago. The main function of them is to make predictions unexplained from the logical point of view (Fliginskikh, 2014 (2), p. 157). Superstitions always played a great role in the life of all peoples, especially in the events connected with different rites of passages (Fliginskikh, 2014 (1), p. 110). Superstitions present verbal (oral and written) texts in the form of sentences.

\section{MATERIALS AND METHODS}

The linguistic analysis which is presented in this paper is based on 395 English and 371 Russian superstitions. The main methods used for the research are the method of parallel interlingual comparison based on analogy, as well as comparative-typological and contrastive-descriptive methods. They helped to define similarities in languages of different languages families and the differences inherent in each language separately. In addition to the main method, the following ones were also applied: a descriptive method was used for observing the linguistic material of the superstition content as texts of a language; method of component analysis was used in studying the plan of the content of individual superstitions in two languages, implying the decomposition of the meaning into minimal semantic components. As for the practical methods, a continuous sampling method, registration and processing of the data received occurred necessary. All the superstitions for the analysis were taken from different sources.

For the English superstitions: Black Cats and April Fools by H. Oliver (2006), Strange and Fascinating Superstitions by Cl. De Lys (2005), The Encyclopedia of Superstitions by R. Webster (2009), Multilanguage Dictionary of Superstitions and Omens by D. Puccio (2013), The Story of the World's Most Notorious Superstition by N. Lachenmeyer (2006), Superstitions: 1,013 of the World's Wackiest Myths, Fables \& Old Wives Tales by D.J. Murrel (2008), Oxford Dictionary of Superstitions by I. Opie, M. Tatem (2005), Omens and Superstitions by S.M. Brisher (2002), Superstitions of Victorian England by E. Kouti, N. Harsa (2012).

For the Russian superstitions: Everyday life of a Noble Class of Pushkin Epoch. Omens and Superstitions by E.V. Lavrentyeva (2006), Superstitions or Prejudices by Yu.V. Shcheglova (2007), Multilanguage Dictionary of Superstitions and Omens by D. Puccio (2013), Black Cat with an Empty Bucket. Folk Omens and Superstitions by E.G. Lebedeva (2007), articles in the collections of historical and ethnographical essays (Glukhov, 2012; Family rituals..., 2014, p. 102-112).

\section{RESULTS AND DISCUSSION}

The study presents two analysis of the syntax of superstitious texts. The first one is structural syntax analysis. It describes the superstitious texts from the point of view of the structure and constituent components. The second one is functional syntax analysis. It describes the structure of the superstitious texts with different functions.

\subsection{Structural Syntax Analysis}

Talking about the structure of sentences, there can be distinguished simple and composite sentences. Simple sentences consist principal parts, such as the subject and the predicate, and secondary parts, such as the attribute, the object and the adverbial modifier.

A composite sentence consists of two or more simple sentences joined together. The component parts of a composite sentence are called clauses. The relationship between the clauses may be that of coordination and subordination. In the case of coordination there is a compound sentence whose clauses are independent of each other syntactically.

In the case of subordination, one of the syntactic functions within a simple sentence is expressed by clause thereby forming a complex sentence. The basic structure is called the principal clause; the clause performing some syntactic function within the principal clause is termed a subordinate clause. There are different types of subordinate clauses depending on the type of subordination. The most wide-spread of them: subject clauses, predicate clauses, object clauses, adverbial clauses of time, place and direction, cause, purpose, condition, concession, consequence, and comparison (Badina, 2012, p. 91-102). Let us consider the types of sentences used to build the texts of superstitions.

\subsubsection{Simple Sentence}

A simple sentence which has both the subject and the predicate is known as a two-member sentence:

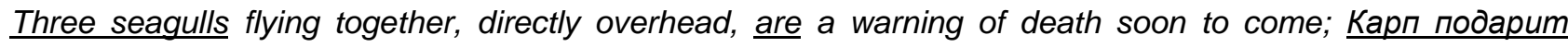


влюбленным удачу.

Sentences which consist only of the subject or the predicate are termed one-member sentences. Such sentences are known as elliptical sentences: Three crows for a wedding; При бесплодии - носить льняную рубашку (помогает от всего).

Sentences which consist only of the predicate are very often sentences with the verb in the Imperative mood which may have a positive or a negative form: Don't knit a pair of socks for your boyfriend; в зеркало вместе с подругой.

As for the English language, it has special constructions that do not exist in the Russian language. They are known as adjective-infinitive construction and construction with the passive verb. Adjective-infinitive construction has the scheme: it + is (was) + Adj + to + Verb: It is unlucky to drop a love letter on the way to a mailbox. Construction with the passive verb has a similar structure, but there is a definite subject and a passive-voice verb instead of an adjective: Subject + is (was) + Pas. Verb + to + Verb. The most common passive-voice verbs are said, considered, thought: Three candles burning on a table are said to predict a funeral, but some people believe it means there will be a wedding soon; A single flower from a bride's bouquet was traditionally thought to be lucky; It was considered very unlucky to compliment a child because this could attract the envy of witches and evil spirits. Superstitions with such constructions very often have common predictions with words lucky/unlucky.

\subsubsection{Compound Sentence}

Two simple sentences (clauses) may be joined by coordination, and in this case they are called compound sentences. The connection of the two clauses is executed by some coordinating conjunctions or asyndetically: The luckiest number for crosses is three, and it is enough to show your love; Couples had to avoid the banks of canal or ponds, bridges, valleys, or - worst of all - crossroads, they turn love and respect into bitterness and hatred; Не разводите у дома плющ, он отдаляет от дома мужчин; Опасно купаться без креста в полдень или в полночь, легко можно стать жертвой русалки или водяного.

\subsubsection{Complex Sentence with Adverbial Clause of Consequence}

Two simple sentences (clauses) may be joined by subordination, and in this case they are called complex sentences. The most wide-spread types of complex sentences are those with adverbial clauses of consequence and condition. The complex sentences with adverbial clauses of consequence are more peculiar for the Russian language, but there are some English examples. There two types of consequences: common and definite.

\section{Common consequence}

A sentence with a common consequence presents some common result that may appear after the action. In the Russian language the common consequence is presented by the preposition $\kappa$ (to) and a Noun with a common meaning: it is usually good or bad luck, happiness or unhappiness, sorrows, etc.: Poдumьcя 8 сорочке - к счастью; Не следует покупать в подарок цепочку с крестом - это к несчастью.

\section{Definite consequence}

A sentence with a definite consequence presents some concrete result that may appear after the action. Among such consequences we can name a date, a lover, a wedding, a kiss, a baby, a death, etc. In the English language the definite consequence is presented with the help of conjunctions so that; in the Russian language it is presented by the preposition $\kappa(t o)$ and a Noun with a concrete meaning: Bridesmaids are dressed much like the bride so that any evil spirits will be confused and not know which maiden to target; Яблоко со стола упало - к свиданию с возлюбленной; Увидеть падающую звезду - к скорой смерти своей или близкого.

\subsubsection{Complex Sentence with Adverbial Clause of Condition}

The complex sentences with adverbial clauses of condition are typical for both English and Russian languages. It should be noted that they are most wide-spread types of sentences among superstitions in general. The principal clause presents the action, and the subordinate clause notes the condition.

A special conjunction used for this type of sentences is if/если. The verbs can have a form of different tenses: If a couple first catch sight of each other in a mirror, they will have a happy marriage; If you are a bridesmaid more than three times you will never get married; Если прямо перед крещением в иеркви отпели покойника, то это может плохо сказаться на будущем ребёнка; Если девица ушибет 
локоть, значит, ее вспомнил милый.

\subsection{Functional Syntax Analysis}

To characterize functions of the supersittions, one should refer to the classification of G.L. Permyakov (Permyakov, 1988, p. 88-89). He identifies seven pragmatic functions of paroemiae or seven practical purposes of paroemiae usage. We consider it necessary to take modeling, instructive, prognostic, and ornamental functions.

Following M.I. Zakirov ${ }^{1}$, we also distinguish cumulative, translational, and cognitive functions. F.T. Fidarova ${ }^{2}$ identifies three functions of superstition: cognitive and regulatory functions coincide with prognostic and modelling ones, respectively, communicative function considers folklore works as a fixed text.

Let's consider all the functions in more detail:

1) Prognostic (predictive) function is the main one for superstitions, as their essence is to predict the future;

2) Modeling (regulatory) function can help to influence the representatives of the linguocultural society. Superstition presents a verbal model or pattern of behavior suitable for a particular life or logical situation, i.e. it regulates the way of life and sets a specific program of actions;

3) Instructive (educational) function. Superstition presents norms of behaviour, creates certain stereotypes and patterns of behaviour and thinking;

4) Cumulative function reflects all the experience accumulated by previous generations;

5) Translational function helps to pass on the accumulated experience to subsequent generations, which ensures continuity;

6) Cognitive (informative) function presents informative content of superstitions;

7) Ornamental (aesthetic) function serves to decorate speech. Rhythm and rhyme in superstitions, a clear choice of words, the use of metaphors and similes give the listener an aesthetic pleasure from listening to and repeating these texts. In addition, this function helps to ensure continuous repetition of superstitions, which influence the memorization of life rules;

8) Communicative function. Superstitions as a number of other paroemiae were created for oral use and transmitted orally, and only later were they recorded as a written text.

All these functions helped to define four main types of syntactic patterns connected with functional syntax.

\subsubsection{Prognostic Superstitions}

Prognostic superstitions are a group of superstitions predicting future events on the basis of what is happening now. They just describe the situation and possible development of the action. It does not depend on personal wishes and intention of the actors. It does not present the assessment of the event, does not give any piece of advice and does not warn. Predictions may be both positive and negative. But sometimes they may be continued by a piece of advice how to ensure against negative consequences (a mix of prognostic and intention superstitions).

Such superstitions are characterised by the use of the preposition if/eсли, nouns good luck, bad luck, sign/знак, признак, verbs mean/означать: It was a good luck to call a child by a chosen name before baptizing; A pearl engagement ring is said to bring bad luck because its shape echoes that of a tear; Серебряная ложка в тесте означает богатство; Если роды будут в доме всем известны, то они будут тяжелые.

\subsubsection{Intention Superstitions}

Intention superstitions are a group of superstitions that guide people, suggest what actions need to be performed in order to achieve the desired or avoid some problems. There are several types of constructions for intention superstitions.

Popular characteristic of intention superstitions is the use of the verbs shall, should/должен, следует,

${ }^{1}$ 27. M.I. Zakirov. The Concept of Water in Russian and Tatar Folk Omens. PhD Thesis in Philology, p. 41-43.

${ }^{2}$ 32. F.T. Fidarova. The Logical and Discursive Structure of the Texts of the Folklore Genre of Omens and Superstitions: On the Material of the Texts of French and Russian Omens. PhD Thesis in Philology, p. 23-26. 
need/нужно: If a stranger comes to the house and there is an unbaptized baby in the family, especially a girl, a guest shall drink or eat something not to carry away its beauty; The clock should be stopped at the time of death, as its running will bring ill luck. In the Russian language these verbs are often accompanied by the adverbial clause of purpose with conjunction чтобы (in order to): Чтобы избавить ребенка от сәлаза, его старую одежду выбрасывают вместе со старым веником в окно; Невеста за столом должна дернуть скатерть, чтобы другая девица поскорее вышла замуж.

The typical structure for the intention superstitions in the English language is the Imperative mood: Wear some article of clothing of a pregnant woman; in the Russian language - the Infinitive: Bupacmumb 6 спальне фокус, ухаживать за ним, как за ребенком.

\subsubsection{Taboo Superstitions}

Taboo superstitions are a group of superstitions which is opposite to the previous group. Superstitions of this group also guide a person, but they tell what actions should not be taking and sometimes even declare a strict taboo for some actions, predicting bad consequences. Some taboo superstitions present only the action that is forbidden, other taboo superstitions talk about the consequences.

The texts of such superstitions are constructed using such words and word combinations as shall not, should not/не должен, не следует, do nоt/не, нельзя, Imperative mood, indefinite-personal and generalizedpersonal sentences: A pregnant woman shall not spin not to make a running knot for a baby; Don't knit a pair of socks for your boyfriend or he'll walk away from you; Сама беременная не должна ребенку приданое готовить, не то он мертвым родится; Пустую колыбель нельзя качать, значит, будущему ребенку в ней места нет.

\subsubsection{Apotropaic Superstitions}

Apotropaic superstitions are a group of superstitions predicting the possibilities of protection from negative influences. Personal belongings, household goods, parts of nature, as well as actions are very often used as protective elements. There is a number of universal objects and actions that are considered protective in both English and Russian cultures.

Silver was considered to be a protective metal and red colour - an apotropaic one, as red ribbons and threads were used very often (Fliginskikh, 2016, p. 113). Both elements were applied to protect pregnant women, newborns, and newlyweds: Silver or iron amulets were once placed in a baby's crib and sometimes a knife was tied to the crib; Даже в жаркий сенокосный период невесте не разрешалось снимать тяжелые украшения из серебряных монет; Sometimes a knife was tied to the crib as well as red string, a traditional protection against witches; Платки и шали использовались для укрытия невесты в день свадьбы, чаще всего они имели красный ивет или преобладали красные тона,

Another universal component is a veil used to cover a bride from strangers' eyes during the wedding ceremony: A veil protects a bride from the evil eye, or ever-present evil spirits; $\underline{\Phi a m a ~-~ э т о ~ з а щ и т а ~ o m ~}$ злых глаз.

A universal action that can be mentioned is covering or turning a mirror in the house of a deceased person: It was custom to cover mirrors with dark cloth following a death to protect those living in the house from the spirit of the deceased; Если кто-то в доме умирает, зеркала в доме завешивают, смотреть в них нельзя.

\section{CONCLUSION}

1) The text of superstitions may be presented in the form of both simple and composite sentences in the English and Russian languages. Superstitions in the form of composite sentences may be both compound and complex. Most popular complex sentences of superstitions are sentences with adverbial clause of consequence and condition.

2) Superstitions in the form of simple sentences may be both two-member and one-member. One-member simple sentences are called elliptical. Sentences which consist only of the predicate are very often sentences with the verb in the Imperative mood.

3) The English language is characterized by special constructions that do not exist in the Russian language: adjective-infinitive construction and construction with the passive verb

4) Compound sentences of superstitions may be with coordination or asyndetic. Such types of sentences are very rear in both languages under study. 
5) There are two types of complex sentences of superstitions with adverbial clause of consequence: with common and definite consequence. Such sentences are more typical of the Russian language.

6) Complex sentences of superstitions with adverbial clause of condition are the most wide-spread type of sentences for superstitions in the English and Russian languages.

7) Prognostic, intention, taboo, and apotropaic superstitions are present in both languages and could have different structure.

8) Prognostic superstitions are often presented in the form of complex sentences with adverbial clause of condition

9) Intention and taboo superstitions are characterized by modal verbs in the positive or negative forms and the Imperative mood.

10) Apotropaic superstitions are characterized mostly by the constituent components meaning different types of protective talismans and charms.

\section{REFERENCE LIST}

Badina, K. Yu. (2012). Theoretical Grammar.

Brisher, S. M. (2002) Omens and Superstitions.

Family Rituals of the Peoples Living in the Middle Volga Region (Historical and Ethnographical Essays). Collection of Articles (1990).

Fliginskikh, E. E. (2014) Ritual Superstitions in the Culture of Russian People. Vestnik of Mari State University, 3 (15).

Fliginskikh, E. E. (2016) The Comparative Characteristics of Colour Naming in the Ritual superstitions of the Russian, English, and Mari Languages. Innovative Technologies in Teaching Foreign Languages: from Theory to Practice: Proceedings of the III Regional Scientific and Practical Conference.

Fliginskikh, E. E. (2014) Towards a Definition of a Term 'Superstition'. Vestnik of Chuvash State University, 1.

Glukhov, V. A. \& Glukhova, N. N. (2012) Systems of Symbols in the Songs of Finno-Ugrians of Ural and Volga Regions: Monograph.

Kouti, E. \& Harsa N. (2012) Superstitions of Victorian England.

Lavrentyeva, E. V. (2006) Everyday life of a Noble Class of Pushkin Epoch. Omens and Superstitions.

Lebedeva, E. G. (2007) Black Cat with an Empty Bucket. Folk Omens and Superstitions.

Lachenmeyer, N. (2006) The Story of the World's Most Notorious Superstition.

Lys, Cl. de (2005) 8,414 Strange and Fascinating Superstitions.

Murrel, D. J. (2008) Superstitions: 1,013 of the World's Wackiest Myths, Fables \& Old Wives Tales.

Oliver, H. (2006) Black Cats and April Fools.

Opie, I. \& Tatem, M. (2005) Oxford Dictionary of Superstition.

Permyakov, G. L. (1988). Basics of structural Paroemiology.

Puccio, D. (2013) Multilanguage Dictionary of Superstitions and Omens.

Shcheglova, Yu. V. (2007) Superstitions or Prejudices.

Webster, R. (2009) The Encyclopedia of Superstitions. 